\title{
PHENELZINE PRODUCES SUBSENSITIVITY TO NICOTINE
}

\author{
STEVEN C. DILSAVER ${ }^{1}$, MEENATSHISUNDANAN HARIHARAN ${ }^{2}$, \\ ROBIN K. DAVIDSON ${ }^{2}$ \\ 'Department of Psychiatry and Behavioral sciences, \\ school of Medicine, University of Texas, Hougton \\ clinical Research Unit \\ Harria County Pgychiatric Center \\ Houston, Texas \\ and ${ }^{2}$ Department of Pgychiatry and Mental Health Research \\ University of Michigan U.S.A.
}

(Final form, August 1992)

\begin{abstract}
Dilsaver, Steven C., MeenatBhlaundanan Harlharan, Robin K. Davidson: Phenelzine Produces subsensitivity to Nicotine. Prog. Neuro-Psychopharmacol. \& Biol. Prychiat. $1993,17(5): 847-860$.

1. The authors attempted to detect a possible effect of treatment with phenelzine on a physiological response to nicotine in the rat.

2. Positive findings in an animal model suggest the feasibility of more complicated experiments in animals and the possibility of studies involving human subjects.

3. Treatment of Sprague Dawley rats $(\mathrm{n}=10)$ with phenelzine sulfate $(15.0 \mathrm{mg} / \mathrm{kg}$ ip) every 48 hours for 14 days was associated with a 73.38 decrease in the hypothermic response to nicotine.

4. Treatment with phenelzine did not enhance the rate of elimination of nicotine.

5. The authors discuss a possible relationship between changes in nicotinic mechanisms and the therapeutic actions of drugs used to treat affective iliness.
\end{abstract}

Keywords: affective disorders, cholinergic, depression, monoamine oxidase, monoamine oxidase inhibitors, nicotine, phenelzine, receptors, thermoregulation

Abbreyiationg: high pressure liquid chromatography (HPLC); intra-peritoneal (ip); standard error of the mean (SEM); ultraviolet (UV)

\section{Introduction}

There is great deal of interest in the relationship between smoking and depression (Breslau et al., 1991; Churchill et al., 1989; Covey et. al., 1990; Dilaaver et al., 1990; Glassman et al., 1988, 1990). Subjects participating in the National Institute of Mental Health sponsored Epidemiologic Catchment Area (ECA) study who had a history of major depression were significantly more likely to have had a history of regularly smoking than those individuals with and without another psychiatric disorder. Data from this study also indicated that individuals who were depressed were less successful in their efforts to stop smoking than non-affectively ill subjects. Breslau and Kilby (1991) recently reported that the probability of participants in the study who smoked would have onset of their first episode of major depression during a 14 month follow-up interval was much higher than expected by chance. These data have created interest in the interaction of drugs used to treat depression with 
nicotinic cholinergic mechanisms.

Measurement of the thermic response to nicotine before, in the course of, and following chronic treatment is used to screen agents for possible effects on a nicotinic mechanism. We used this strategy to test the hypothesis that treatment with phenelzine has nicotinic effects. This drug is a non-specific and irreversible inhibitor of monoamine oxidase. Agents with this property are effective antidepressants (Liebowitz et al., 1984; Paykel, 1989). The monoamine oxidase inhibitors, in contrast to the tricyclic antidepressants, do not bind to muscarinic (Goldman and Ericson, 1983; Snyder and Yamamura, 1977; Tollefson et al., 1982) or nicotinic acetylcholine receptors (Schofield et al., 1981; Shaker et al., 1981). These findings have kindled interest in the interaction between drugs used to treat affective illness and nicotinic cholinergic mechanisms.

The data presented indicate that treatment with phenelzine blunts sensitivity nicotine.

\section{Materials and Methods}

Change in core body temperature in response to the ip injection of $1.0 \mathrm{mg} / \mathrm{kg}$ of nicotine (base) before and following 7 and 14 days of treatment with phenelzine sulfate was measured in Experiment 1. This procedure has proved useful and reliable in screening the effects of drugs (Dilsaver and Davidson, $1987 \mathrm{a}, \mathrm{b}$; Dilsaver and Hariharan, 1989 a,b; Dilsaver and Hariharan, 1988; Dilsaver and Majchrzak, 1990; Dilsaver et al., 1987, 1988, 1989, Majchrzak and Dilsaver 1990), drug withdrawal (Dilsaver and Majchrzak, 1987), chronic stress (Dilsaver 1988c; Dilsaver et al., 1986, 1990; Peck et al., 1991) and treatment with bright light (Dilsaver 1988a, 1990a; Dilsaver and Majchrzak, 1988; Overstreet et al., $1990 \mathrm{a}, \mathrm{b}$ ) on muscarinic and nicotinic cholinergic mechanisms (Dilsaver and Alessi, 1988 for a review of the method).

The rats used in Experiment 1 continued to receive the same dose of phenelzine sulfate every 48 hours for an additional week. Experiment $\$ 2$ involved the measurement of the plasma concentrations of nicotine and cotinine in these animals 30 minutes after the ip injection of $1.0 \mathrm{mg} / \mathrm{kg}$ of nicotine on day 21 of the study. Nicotine and cotinine levels were also measured under identical conditions in a saline treated control group.

\section{Animale}

Ten (10) adult male Sprague Dawley rats were treated with phenelzine. Their mean mass ( \pm SEK) was $265.8 \pm 8.5 \mathrm{~g}$ at the start of the study. The mean mass of the 8 saline control animals used in Experiment 2 was $267.5 \pm 2.5 \mathrm{~g}$. The animals were purchased from Harlan Laboratorles (Indianapolis, IN). Care was provided by the University of Michigan Laboratory Animal Medicine.

\section{Pharmaceuticals}

Phenelzine sulfate, nicotine (base) and cotinine were purchased from sigma 
Chemical company (St. Louis, Mo, U.S.A). All references to concentrations or doses of nicotine and phenelzine refer to the base and salt forms respectively.

\section{Nicotine challenges}

All challenges with nicotine started at 12:00 pm. Core temperature was measured immediately before the ip injection of $1.0 \mathrm{mg} / \mathrm{kg}$ of nicotine and at $10 \mathrm{minute}$ intervals thereafter for $120 \mathrm{minutes.} \mathrm{Challenges} 2$ and 3 occurred on the 7 th and 15 th days of treatment with phenelzine, respectively.

\section{The Administration of Phenelzine}

Phenelzine was given by ip injection at 4:00 pm every 48 hours. The dose of phenelzine was $15 \mathrm{mg} / \mathrm{kg}$ through the entire period of treatment. The second challenge with nicotine followed the injectione of phenelzine Days 2, 4, and 6 of the experiment. The injection of nicotine followed the dose of phenelzine given on Day 6 by 20 hours. The third challenge with nicotine followed additional injections of phenelzine on Days 8, 10, 12 and 14 of the experiment. Nicotine was Injected 20 hours following the dose of phenelzine given on the 14th day of the study.

\section{Experimental procedure}

\section{Experiment 1}

core temperature was measured using biotelemetry. The method is described below. The first measurement of temperature is referred to as the animal's "baseline." This is also referred to as the core temperature at $t$ ime $(t)=0$. Baseline core temperature was measured prior to touching the animal. This is noteworthy as merely handling the rat rapidly produces hyperthermia (Dilsaver and Majchrzak, 1990; Dilsaver et al., 1992).

Temperature at each of the 12 time points following $t=0$ was transformed into a unit of thermic response by subtracting core temperature at $t=0$. Thus, a negative number is obtained if core temperature decreases. The average of these 12 measurements is the mean thermic response of an individual rat. significance of change in the thermic response of individual animals to nicotine was determined by pairing the thermic response of that animal at each of the 12 time points before and after 7 and 14 days of treatment. The mean thermic response of each animal was then used to determine whether the change in thermic response of the sample was aignificant.

\section{Experiment 2}

The effect of treatment with phenelzine on the rate of elimination of nicotine was measured by injecting $1.0 \mathrm{mg} / \mathrm{kg}$ of nicotine into the phenelzine ( $\mathrm{n}=10$ ) and $\mathrm{Ba}$ ine $(n=8)$ treated rats. The experimental and control groups received ip injections of $15.0 \mathrm{mg} / \mathrm{kg}(1.0 \mathrm{ml} / \mathrm{kg})$ of phenelzine and normal saline $(1 \mathrm{ml} / \mathrm{kg})$, respectively, on Days $2,4,6,8,10,12,14,16,18$ and 20 of the study. 
Nicotine was injected the morning of the $218 t$ day of the study. Blood was drawn by cardiac puncture and placed into hoparinized tubes 30 minutes following the injection of nicotine. Plasma was then frozen until the concentration of nicotine and cotinine were measured using an HPLC assay with a UV detector (Hariharan et al., 1988).

\section{Measurement of core Temperature}

Core temperature was measured using the Model VM Mini-Mitter (Mini-Mitter Corp., Sun River, $O R$ ). This instrument consists of a thermosensor and radio-transmitter which emits AM waves at a rate directly proportional to temperature. Each Mini-Mitter is encased in a waterproof substance (Kerr sticky Wax ${ }^{R}$ ) and is capable of reliable operation for more than four months at the normal core temperature of the rat.

The Mini-Mitter is calibrated each time the casing 1s broken. The procedure used to calibrate the Mini-Mitter requires measurement of the rate of emisgion of AM waves at three or more temperatures in a temperature controlled water bath (Precision Instruments, 50). These data are used to calculate a linear regression equation. The equation is then transformed so that " $y$ " (the dependent variable) is temperature and " $x$ " (the independent variable) is the time required to emit a fixed number of aM waves. The Mini-Mitter is then implanted into the peritoneal cavity using ether as a general anesthetic or the combination of ketamine and a local anesthetic (xylazine). The animals are allowed at least 5 days to recover from the implantation procedure.

The Mini-Mitter yields reliable and valid reaults when used in psychopharmacological studies in which the magnitude of effect is of the order relevant to this report (Dilsaver et al., 1990).

Table 1 highlights the time course of the events.

Table 1

Time Course of the Event:

1. The telemetric thermosensors (Mini-Mitters) are calibrated.

2. The thermosensors are implanted into the peritoneal cavity.

3. The animals are allowed 5 or more days to recover from the implantation procedure.

Day 1 of the study

4. The animals are challenged with $1.0 \mathrm{mg} / \mathrm{kg}$ of nicotine (base) by ip injection at 12:00 pm. This challenge provides the pretreatment response of each rat to nicotine.

\section{Days 2, 4 and 6}

5. The experimental and control groups recelve $15.0 \mathrm{mg} / \mathrm{kg}$ (volume $=1 \mathrm{ml} / \mathrm{kg}$ ). of phenelzine sulfate and $1.0 \mathrm{ml} / \mathrm{kg}$ salline, respectively by ip injection at $4: 00 \mathrm{pm}$.

Day 7

6. The animals in the experimental group are challenged with nicotine at 12:00 pm on Day 7. The fourth dose of phenelzine or saline is given about 4 hours following the infection of nicotine. 
Days 8, 10, 12 and 14

7. Doses of phenelzine sulfate or saline are administered.

Day 15

8. The animale are challenged with nicotine for the third time.

Day 16,18 , and 20

9. Doges of phenelzine sulfate or saline are administered.

Dag 21

10. Animals in both the experimental and control groups receive an ip injection of $1.0 \mathrm{mg}$ of nicotine (base). Blood is collected by cardiac puncture 30 minutes later and injected into heparinized tubes. Aliquots of plasma are then frozen until an HPLC asgay with UV detection is used to measure the concentrations of

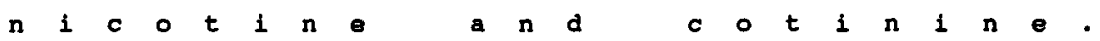

\section{Aseay of Nicoting}

Plasma levels of nicotine and cotinine were meagured using an HPLC asgay coupled to UV detector. 2-phenylimidazole (Alrich) was used as an internal standard. The mobile phase consieted of $30 \mathrm{mr}$ citrate buffer, 7 acetonitrile and $2 \mathrm{~ms}$ sodium hepatanesulfonate at a PH of 5.0. A C-18 column (Shandon, state College, PA) with a length of $150 \mathrm{~mm}$ and diameter of $2 \mathrm{~mm}$ was used. Evaporation of the organic phase was quickened by a flow of nitrogen gas. The reaidue was then reconstituted with 5 microliters of the mobile phase. Twenty microliters was then injected into the column. The sensitivity of the assay is 1 and $2 \mathrm{ng} / \mathrm{ml}$ for nicotine and cotinine, respectively. The assay ylelds linear results from 0 to $600 \mathrm{ng} / \mathrm{ml}$ for both analysates. All the reagents in the assay are HPLC grade (Hariharan, et al., 1988 ).

\section{Statiatical Analygis}

All data in Experiment 1 were subject to analysis using student's paired $t-t e s t$. Data in Experiment 2 were analyzed using student's two sample t-teat. All measures of variance in the text refer to the SEM.

\section{Experiment 1}

\section{Regults}

Table 2 summarizes the results of this experiment. Nine of the 10 rats exhibited blunting of their thermic response to nicotine at $p<0.005$ on Day 15 . Thus, the effect of treatment with the monoamine oxidase inhibitor was not restricted to a few animals.

The mean thermic response of the sample prior to treatment with phenelzine was $1.5 \pm 0.2^{\circ} \mathrm{C}$. The mean reaponse was $-1.2 \pm 0.2^{\circ} \mathrm{C}$ after 7 days of treatment (i.e., three doses of phenelzine sulfate). The mean thermic response then decreaged to -0.4 $\pm 0.1{ }^{\circ} \mathrm{C}$. (df $=9, t=3.93, p<0.0035$ ) following 14 days of treatment (1.e., after 7 doses of phenelzine gulfate). The raw data are pregented in Table 2 . Figure 1 presents the resultg of the study. 
Table 2

Sumary of The Results of Experiment 2

Presentation of Data Entering into the Analysis for Experiment 1

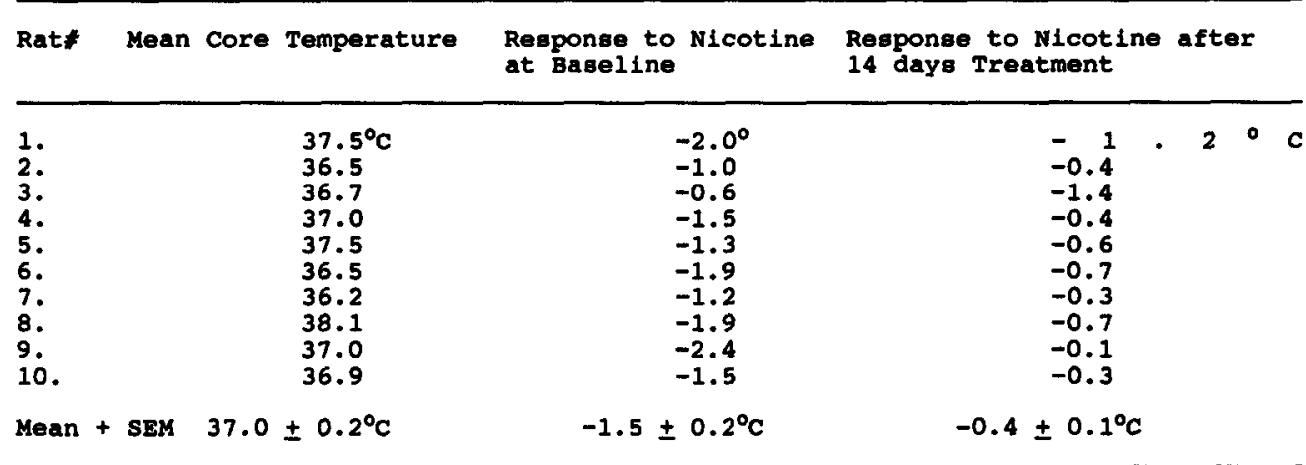

Nine (9) of the 10 ratg exhibited gignificant blunting of the thermic response to nicotine following 14 days of treatment. The exception was rat 3 . All numbers rounded to nearest $1 / 10$.

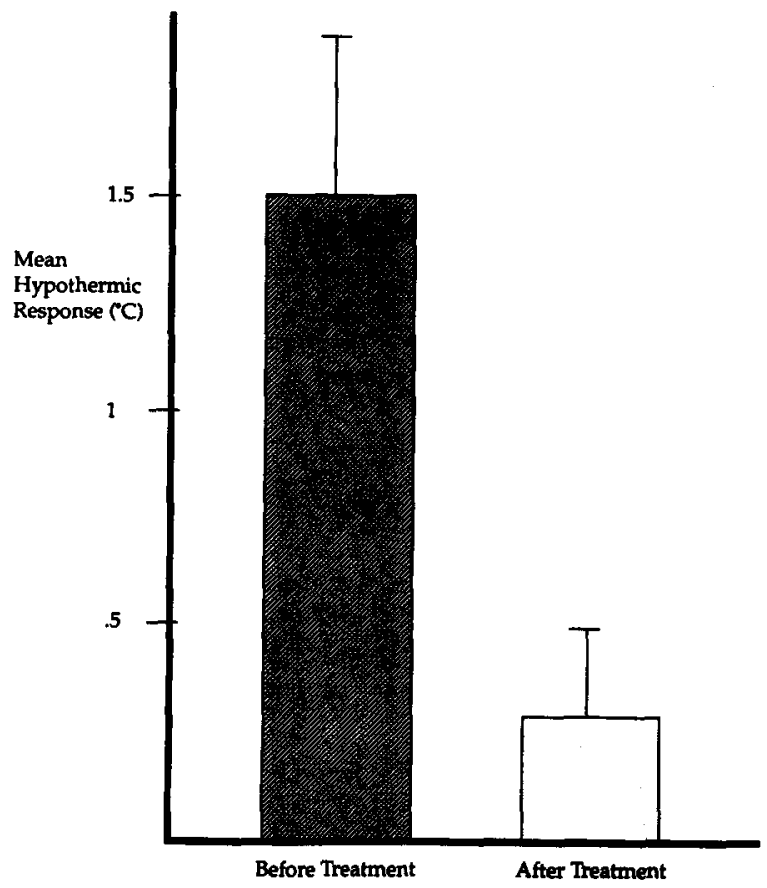

Fig 1. Mean \pm SEM thermic response of 10 sprague Dawley rats to $1.0 \mathrm{mg} / \mathrm{kg}$ of nicotine (base) before and after a 14 day courbe of treatment with $15.0 \mathrm{mg} / \mathrm{kg}$ phenelzine sulfate by ip injection every 48 hours. The change is significant at $p<0.0035$. 


\section{Experiment 2}

Nicotine levels in the experimental and control groups were $447 \pm 27 \mathrm{ng} / \mathrm{ml}$ and 394 $\pm 9.0 \mathrm{ng} / \mathrm{ml}$. (df $=16, t=1.15, p>0.2)$, reapectively. The corresponding levela of cotinine were $230 \pm 21 \mathrm{ng} / \mathrm{ml}$ and $289 \pm 40 \mathrm{ng} / \mathrm{ml}$ (df $=16, t=1.47, \mathrm{p}>0.10$ ), respectively. Neither difference was algnificant.

Table 3 summarizes the results of the experiment.

Tab1e 3

Differences in Nicotine and cotinine Ievels in Phenelaine and saline rreated Rate.

\begin{tabular}{|c|c|c|}
\hline & $\begin{array}{l}\text { Mean level of } \\
\text { nicotine } 30 \\
\text { minutes after } \\
\text { its injection } \\
(1 \mathrm{mg} / \mathrm{kg} \text { ip) }\end{array}$ & $\begin{array}{l}\text { Mean level of } \\
\text { cotinine } 30 \\
\text { minutes after } \\
\text { the injection } \\
\text { of. nicotine }\end{array}$ \\
\hline $\begin{array}{l}\text { Treatment with } \\
\text { Phenelzine every } \\
48 \text { hourg for } 21 \\
\text { days ( } 10 \text { doses) }\end{array}$ & $447 \pm 27 \mathrm{ng} / \mathrm{ml}$ & $230 \pm 21 \mathrm{ng} / \mathrm{ml}$ \\
\hline $\begin{array}{l}\text { Treatment with } \\
\text { aaline every } 48 \\
\text { hours for } 21 \text { days } \\
\text { (10 doses) }\end{array}$ & $394 \pm 9.0 \mathrm{ng} / \mathrm{ml}$ & $289 \pm 40 \mathrm{ng} / \mathrm{ml}$ \\
\hline $\begin{array}{l}\text { Absolute value of } \\
\text { Difference in } \\
\text { concentration of } \\
\text { nicotine (phenelzine } \\
\text { relative to aline group) }\end{array}$ & 11.98 (ns) & 25.78 (ns) \\
\hline
\end{tabular}

The rate of elimination of nicotine did not differ between groupe. The percent (8) difference $=$ absolute value of [(level of nicotine or cotinine in the phenelzine group) - (the level of nicotine or cotinine in the aaline group) alvided by the levels of nicotine of cotinine in the phenelizine group) ) (100).

\section{Discugaton}

Treatment with phenelzine produced time-dependent aubsensitivity to the thermic effect of nicotine. Thermic responsiveness decreased by 20 and 73 following 7 and 14 days of treatment, respectively. This strongly suggests that an acute effect of the monoamine oxidase inhibitor does not account for the findings. Experiment 2 Indicates that the animale receiving phenelzine and saline every 48 hours for 21 days had similax plasma nicotine and cotinine levels 30 minutes after the ip injection of $1.0 \mathrm{mg} / \mathrm{kg}$ of nicotine (base). This suggeats that decreased responsivenesa to nicotine is not due to an increase in itg rate of elimination.

The injection of nicotine at a doee of $1.0 \mathrm{mg} / \mathrm{kg}$ ip at 7 day intervals does not produce a caryover effect (Dilsaver et al, 1988). It is therefore probable that decreased sensitivity to nicotine is due to a pharmacodynamic effect of treatment with phenelzine.

Cholineralc Propertieg of Drugs Used to Treat Affective Disorderg

Jaffe and sharpless (1968) and Friedman et al. (1969) demonetrated that chronic treatment with an antimuscarinic agent produces supersensitivity to a muscarinic 
receptor agonist in an animal model. Muscarinic receptor antagonists were subsequently demonstrated to produce upregulation of muscarinic receptors (Dilsaver 1988b; Shifrin and Klein, 1980; Simian and Klein, 1979; Taylor et al., 1979; Yamada et al., 1983).

The affinities of peripheral and central muscarinic receptors for many pharmacological treatments for depression have been measured (Blackwell et al., 1978; Goldman and Erickson, 1983; Rehavi et al., 1980 Richelson and Dinninetz-Romero, 1977; Snyder and Yamamura, 1977; Szabdi et al., 1972; Tollefson et al., 1982). The tricyclic antidepressants specifically bind to these receptors. Chronic treatment with these drugs produces compensatory biochemical and physiological changes in both the rat and human subjects (Dilsaver 1989; Dilsaver and Greden, 1983 and 1984; Dilsaver and Davidson, 1988; Dilsaver et al., $1983 \mathrm{a}, \mathrm{b}, 1987$; Nomura et al., 1982 $a, b)$. These changes constitute chemically induced denervation supersensitivity. It is manifested by enhanced responeiveness to acetylcholine and muscarinic receptor agonists.

Phenelzine is devoid of affinity for the muscarinic receptors (Snyder and Yamamura, 1977). The antimuscarinic-like side-effects produced by this drug are likely due to its actions on noradrenergic systems (Dilsaver $1986 \mathrm{a}, \mathrm{b}, \mathrm{c}$; Dilsaver and Coffman, 1989). Isoproterenol is an example of a arug devoid of direct

effects on muscarinic receptors but which can appear to have adrenergic properties. Treatment with this beta-blocker increases the density of muscarinic receptors and the acetylcholine-mediated activation of ornithine carboxylase in the myocardium of the rat (Nomura et $a 1,1982 b$ ) by virtue of its interaction with adrenergic neurons.

\section{Somatic Treatments Blunting the Thermic Response to Nicotine}

The nicotinic properties of somatic treatments for depression have received very little attention. All of the articles included in the MEDLINE database from 1986 to January 1992 are cited in this report. Fluoxetine (Dilsaver and Davidson, 1987a), desipramine (Dilsaver et al., 1989) and bright artificial light (Dilsaver 1988a, 1990a) also produce subsensitivity to nicotine in the rat. In contrast, lithium (Dilsaver and Hariharan, 1989b) and amitriptyline (Dilsaver et al., 1988) enhance the rat's thermic response to nicotine (see Dilsaver and Hariharan, '1989a for a review). These seemingly incompatible findings can be reconciled.

The observation that various treatments for affective illness affect the function of nicotinic mechanisms is compatible with the aminergic theories of its etiology. The nicotinic effects of somatic treatments for the disorders of mood may either be causally or indirectly related to events critical to their mechanism of action. Nicotine promotes the release of norepinephrine in the hypothalamus (Westfall, 1973) and of dopamine within the nigrostriatal and mesolimbic systems (Anderson et al., 1981). Treatments which mobilize nicotinic mechaniams might secondarily activate defective aminergic systems. A treatment which enhances the activity of aminergic mechanisme mlght induce compensatory subsensitization of those nicotinic mechanisms with which it interacts in order to preserve homeostasis.

\section{Relationship between Dose of Nicotine and Effect}

The study reported here employed a single dose of nicotine in a repeated measures 
design. Nicotine rapidly produces tolerance. The use of independent multiple samples is more conducive to studying the effects of multiple doses on an endpoint. The measurement of the relationship of dose of nicotine to thermic change before and after treatment with phenelzine and other agents of interest would be a logical step in an effort to demonstrate that these treatments alter sensitivity to nicotine.

Temperature is an ideal endpoint for this type of study. It is easily measured and is contaminated by minimal variance. The available data suggeat that phenelzine, fluoxetine, bright light, and desipramine will produce a right shift in the doseeffect curve (indicating that a higher dose of nicotine is required to produce a given hypothermic response to nicotine). Amitriptyline and lithium, should produce a left-shift in the curve. These points are illustrated in Fig. 2 .

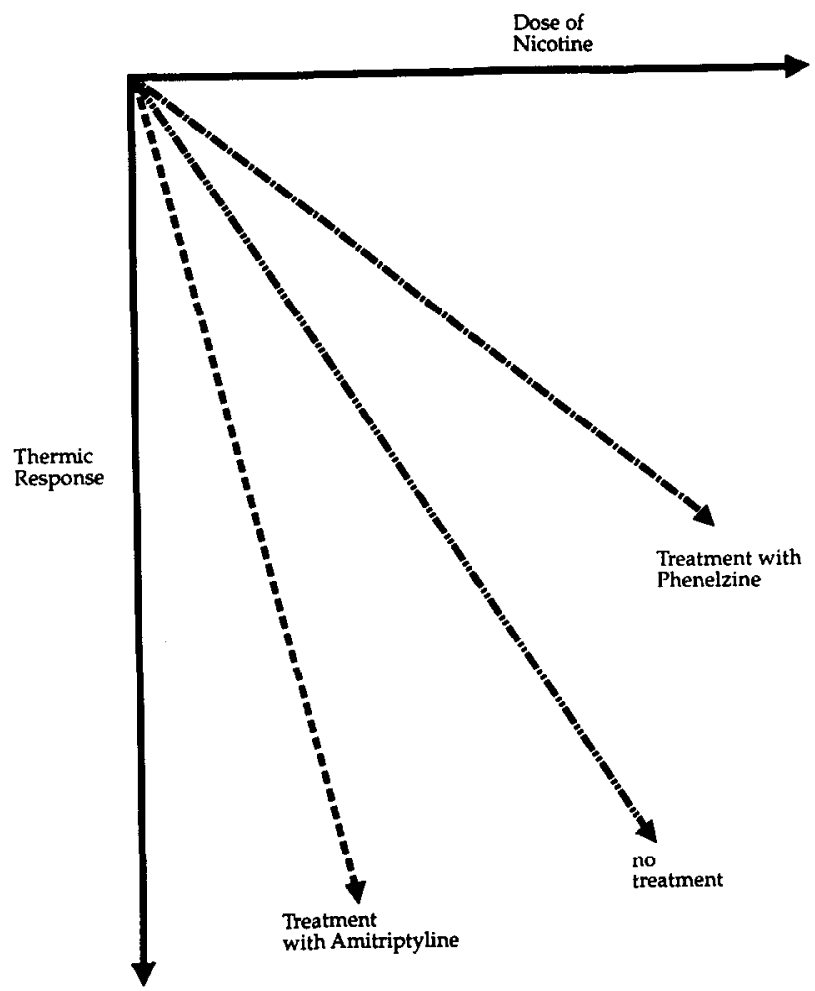

Fig. 2 effects of chronic treatments with amitriptyline and phenalzine. The Chronic administration of all six somatic treatmente for the affective disorders (amitriptyline, desipramine, fluoxetine, lithium, bright light and phenelzine) studied to date dramatically alter the thermic response to nicotine. A single dose of nicotine was used in this and all previously published reports on this topic. studies designed to detect a possible relationship between dose of nicotine and thermic response (dose-response studies) have yet to be conducted. Figure 2 illustrates the hypothetical results of a study of this type. It indicates that chronic treatment with amitriptyline and phenelzine increase and decrease by the left shift of the dose-response curve for the group treated with amitriptyline and the right shift of the dose-response curve of the group treated with phenelzine, relative to the group of recelving no treatment. 


\section{Studies in Human Subtects}

Nicotinic effects of phenelzine are not likely to be related to its mechanism of action if depressed patients in whom it is efficacious do not exhibit altered responsiveness to nicotine. Studies indicating a time-dependent change (such as that reported here) could prove quite important.

The effects of acute and chronic treatment with phenelzine and other drugs used to treat disorders of mood on the responeiveness of human subjects to nicotine can be measured. The effect of intravenous doses of nicotine (Benowitz and Jacob, 1990; Newhouse et al., 1988) on subjective state, neuroendocrine parameters and body temperature can be measured before and in the course of treatment. Studies of this type are necessary in order to determine whether the finding reported here may have relevance to the mechanism of action of phenelzine.

\section{Limitations of the Use of a Physiological Endpoint}

Documentation that a given type of experimental intervention (e.g. drug treatment) consibtently produces changes in a series of physiological endpoints is an excellent means of isolating a regularity in nature. Isolation of these regularitiea would have once been sufficient data to exercise influence over the way most scientists think. However, the history of science has proceeded from the atudy of events at the organismal to cellular and now molecular levels.

There is a floating concept in the scientific community of Kant's "noumenon" (Rant, 1781). Neumenon refers "the thing itself." It is reality. Kant emphasized that man merely grasps appearances of reality via the all too easily deceived Benses. He labeled that which is perceived "phenomenon". The ideas of noumenon and phenomenon in the sciences are mutable. The isolation of regularities is of the very essence of the scientific process. However, the isolation of regularity in an intact animal is now merely phenomenon (Dilsaver 1990b). The observations reported here draw attention to underlying events which were identified by measuring a physiological endpoint. Basic biochemical and electrophysiological studies designed to characterize the interaction between muscarinic and nicotinic cholinergic mechanisms will be required to effect the move "from phenomenon to mechaniam."

\section{Conclusions}

1. Treatment of the sprague-Dawley rats with phenelzine sulfate, a non-selective monoamine oxidase inhibitor useful in the treatment of depression, resulted in subsensitivity to the hypothermic effect of nicotine.

2. The effect of treatment was robust. Nine (9) of the 10 rats exhibited significant decreases in their hypothermic reaponses to nicotine after 14 days of treatment. The sample exhibited a 73.38 reduction in its hypothermic response.

3. Treatment with phenelzine did not alter the pharmacokinetics of nicotine.

4. Fluoxetine, desipramlne and bright artificial light all reduce the thermic response to nicotine. Desipramine retards the metabolism of nicotine yet affects decreased sengitivity to its hypothermic effect.. 
5. Amitriptyline and lithium enhance the thermic response to nicotine.

6. The authors suggest that at least some somatic treatments for affective illness may either directly or indirectly alter the function of nicotinic oystems. The activation of these systems may enhance the function of aminergic mechanisms. Alternatively, the activation of aminergic mechanisms may produce compensatory subsensitivity of nicotinic systems.

\section{Acknowledaement}

This work was supported by MH00553-02 and the University of Michigan, Department of Psychiatry.

\section{References}

ANDERSON, N. FUXE, R. and AGETI, L.E. (1981) Effects of single injections of nicotine in the ascending dopamine pathways in the rat: Evidence for increase of dopamine turnover in nigrostriatal and mesolimbic dopamine neurons. Acta Physiol. Scand. 12: 4199-4202.

BENOWITZ, M.L. and JACOB, P. (1990) Intravenous nicotine placement suppresses nicotine intake in cigarette smokers. J. Pharmacol. Expt. Therap. 254: 10001005 .

BLACKWELL, B. STEFOPOULOS, A. ENDERS, P. KUZMA R. and ALDOLPHE, A. (1978) Anticholinergic activity of two tricyclic antidepressants. Am. J. Psychiatry 135: 722-724.

BRESLAU, W.H. and RILBY, H. (1990) Nicotine dependence and major depresalon: Prospective study. Presented at the 30th Annual Meeting of the American Collegeo of Neuropsychopharmacology, San Juan, Puerto Rico, December 9-13. Abstracts of Panels and Posters, pg. 110.

BRESLAU, N. RILBEY, M.M. and ANDRESKI P. Nicotine dependence, major depression and anxiety in young adults. Arch. Gen. Paychitary 1099-1074.

CHURCHILL, C.M. PARISER, S.F. LARSON, C.N. and DILSAVER, S.C. (1989). Antidepressants and smoking cessation. Am. J. Psychlatry 146: 1238.

COVEY, L.S. GLASSMAN, A.H. and STETNER, F. (1990) Depression and depreasive gymptoms in amoking cessation. Comp. Prychiatry 31: 350-354.

DILSAVER, S.C. (1986b) Pathophysiology of cholinoceptor super-sensitivity in affective disorders. Biol. Paychiatry 21: 813-829.

DILsAVER, S.C. (1986c) Cholinergic-monoaminergic interactio in the pathophyaiology of affective disorders. Int. Clin. Psychopharmacol. 1: 181-198.

DILSAVER, S.C. (1988a) Artificial light and nicotine subsensitivity. Biol. Peychiatry 24: $437-440$.

DILSAVER, S.C. (1988b) Antimuscarinic agente as substances of abuse: A review. J. Clin. Pgychopharmacol. 8: 14-22.

DIISAVER, S.C. (1988c) Effects of gtress on muscarinic mechanisms Neurosci. Biobehav. Rev. 12: 23-28.

DILSAVER, S.C. (1989) Antidepressant withdrawal syndromes: Phenomenology and pathophysiology. Aota Paychiatr. Scand. 79: 113-117.

DILSAVER, S.C. (1990a) Neurobiologic effects of bright artificial light. Brain Res. Rev. 14: 311-334.

DILSAVER, S.C. (1990b) From phenomenon to mechaniam: An inveatigational atrategy. Prog. In Neuro-Pgychopharmacol. and Biol. Psychiatry 14:449-458. 
DILSAVER, S.C. and ALESSI, N.E. (1988) Temperature as a dependent variable in the study of cholinergic mechanisms. Prog. Neuro-Psychopharmacol. Biol. Paychiat. 12: 1-32.

DILSAVER S.C. and COFFMAN, J.F. (1989) Cholinergic hypothesig of depression: A reappraisal. J. Clin. Peychopharmacol. 9: 173-179.

DILSAVER, S.C., and DAVIDSON, R.K. (1987a) Fluoxetine produces subsensitivity to nicotine. Life Sciences 112: 1165-1169.

DILSAVER, S.C. and DAVIDSON, R.K. (1987b) Cholinergic propertieg of deaipramine and amoxapine: Assessment using a thermoregulation paradigm. Prog. NeuroPaychopharmacol, and Biol. Peychiatry 11: 581-599.

DILSAVER, S.C. and DAVIDSON, R.K. (1988) Cholinergic properties of desipramine and amoxapine: Assessment using a thermoregulation paradigm. Prog. NeuroPaychopharmacol. Biol. Paychiatry. 12: 581-589.

DILSAVER, S.C. and GREDEN, J.F. (1983) Antidepressant withdrawal syndromes: Evidence for supersensitivity of cholinergic systems as an etiologic factor. J. Clin. paychopharmacol. 3: 330 .

DILSAVER, S.C. and GREDEN, J.F. (1984) Antidepressant withdrawal phenomena. Biol. Psychiatry 19: 237-256.

DILSAVER, S.C. and HARIKARAN, M. (1988) Amitriptyline-induced eupergensitivity of a central muscarinic mechanism. Lithium blocks amitriptyline-induced supersensitivity. Psychiatry Res. 25: 181-186.

DILSAVER, S.C. and HARIHARAN, H. (1989a) Nicotinic effects of antidepreggants. In: Hew Directions in Affective Disorders, s. Gershon and B. Lerer (Eds.) pp. 109-112, Springer-Verlag, New York.

DILSAVER, S.C. and HARIHARAN, H. (1989b). Iithium produces supersensitivity to nicotine. Biol. Psychiatry 24: 795-798.

DILSAVER, S.C. KRONFOL, I. SACKELLARES, J.C. and GREDEN, J.F. (1983a) Antidepressant withdrawal syndromes: Evidence supporting the cholinergic overdrive hypothesis. J. Clin. Pchopharmacol. 3: 157-164.

DILSAVER, S.C. and MAJCHRZAK, M.J. (1987) Decreabe in core temperature as an indication of cholinergic overdrive during amitriptyline withdrawal. Biol. Paychiatry 22: 485-1487.

DILSAVER, S.C. MAJCHRZAK, M.H. (1988) Bright artificial light produces subsensitivity to nicotine. Life Sciences 42: 225-230.

DILSAVER, S.C. and MAJCHRZAK, M.J. (1990) Effects of placebo (saline) injections on core temperature in the rat. Prog. Neuropsychopharmacol. Biol. Paychiatry 417-422.

DILSAVER, S.C. FEINBERG, M. and GREDEN, J.F (1983b) Antidepresgant withdrawal symptoms treated with anticholinergic agents. Am. J. PBychiatry 140: 249-251.

DILSAVER, S.C. HARIHARAN, H. and DAVIDSON, R.K. (1989) Desipramine subsensitizes a nicotinic mechanism involved in the regulation of core temperature. Paychiatry Res. 25: 105-108.

DILSAVER, S.C. MAJCHRZAK, M.J. and ALESSI, N.E. (1990) Telemetric measurement of core temperature in pharmacological research: Validity and reliability. Prog. NeuroPoychopharmacol. Blol. Psychlatry 14: 591-596.

DILSAVER, S.C. MAJCHRAZAK, M.J. and ALESSI, N.E. (1988) chronic treatment with amitriptyline produces supersengitivity to nicotine. Biol. Paychiatry 23: 163179 .

DILSAVER, S.C. OVERSTREET, D.H, and PECK, J.A. (1992) Measurement of temperature in the rat by the rectal probe and telemetry yields compatible results. Pharmacol. Biochem. Behavior, in press.

DILSAVER, S.C. PARISER S.F. CHURCHILL, C.M. and LARSON, C.N. (1990b) Is there a relationship between failing efforts to stop amoking and depression? $J$. of Clin. 
Psychopharmacol. 10: 153-154.

DILSAVER, S.C. SNIDER, R.M. and ALESSI, N.E. (1986) stress induces supergensitivity of a cholinergic system in rats. Biol. Psyohiatry 21: 1093-1096.

DILSAVER, S.C. SNIDER, R.M. and ALESSI, N.E. (1987) Amitriptyline eupergensitizes a central cholinergic mechaniam. Biol. Paychiatry 22: 495-507.

DILSAVER, S.C. PARISER, S.F. CHURChILL, C.M. and LARSON. (1990a) Is there a relationship between failing efforts to stop smoking and depression? J. Clin. Paychopharmacol. 10: 153-154.

FRIEDMAN, M.J. JAFFE, J.H. and SHARPLESS, S.K. (1969) central nervous gygtem supersensitivity to pilocarpine after withdrawal of chronically administered scopolamine. J. Pharmacol. Expt. Therapeut. 16: 45-55.

GLASSMAN, A.H. STETENER, F. WALSH, T. RAISMAN, P.B. FLEISS, J.L. COOPER, T.B. and COVEY, L.S. (1988) Heavy smokers, smoking cessation and clonidine. JAMA 259: 2863-2866.

GLASSMAN, A.H. HELZER, J.E. COVEY, J.E. COTTLER, L.B. STETNER, F. TIPP, J.E. And JOHNSON, I. (1990) Smoking cessation and major depression. JAMA 264, $1546-1549$.

GOLDMAN, M.E. and ERICSON, C.K. (1983) Effect of acute and chronic treatment with antidepressant drugs in the central nervous system: Comparison with anticholinergic drugs. Neuropharmacol. 22: 1215-1222.

HARIHARAN, H. VANNOORD, T. and GREDEN, J.F. (1988) A high performance 11quidchromatographic method for routine simultaneous determination of nicotine and cotinine in plasma. Clin. Chemistry 34: 724-729.

JAFFE, J.H. and SHARPLESS, S.K. (1968) Pharmacologic denervation guperBengitivity in the central nervous system. Research Publication of the Association for Research in Nervous and Mental Diseses. United states publiahing office, Washington, D.C. 46 : 226-241.

KANT I. (1781) Critique of Pure Reason. Translated by N.K. Smith, London 1933. pp 311-312.

LIEBOWITZ, M.R. QUITKIN, F.M. STEWART, J.W. MCGARTH, R.J. KARRISON, W. RABKIN, J. TRICARANO, E. MARKOWITZ, J.S, and KLEIN, D.F. (1984) Phenelzine va, imipramine. Arch. Gen. Paychiatry 41: 407-413.

MAJCHRzAR, M.J. and DILSAVER, S.C. (1990) Chronic treatment with ethanol produces supersensitivity to oxotremorine. Progress in Neuro-PBychopharmacol. Biol. Peychiatry 14: $379-386$.

NEWHOUSE, P.A. MELLOW, A. TARIOT, P.N., and BLUMARRT, C.L. (1988) Intravenous nicotine in Alzheimer's disease: A pilot atudy. Psyhchopharmacol. 95: 171-175.

NOMURA. Y. KAJIYAMA, H, and OKAI, K. (1982a) Influence of repeated administration of desmethylimipramine on $B$-adrenergic and muscarinic cholinergic receptors and ${ }^{\circ} \mathrm{Ca}^{++}$binding to cytoplasmic reticulum in rat heart. J. Pharmacol. Expt. Therapeut. 223: $834-846$.

NOMURA, Y. KAJIYAMA. H. and SEGAFA, T. (1982b) Alteration in sensitivity to iBoproterenol and acetylcholine in rat heart after repeated administration of isoproterenol. J. Pharmacol. Expt. Therapeut. 220: 441-445.

OVERSTREET, S.C. DILsAVER, S.C. REZVANI, A. and JANOWSKY, D.s. (1990a) Selective antagonist effects of exposure to bright light on the hypothermic action of ethanol. Alcohol Alcohol. 25: 661-665.

OVERSTREET, D.H. DILSAVER, S.C. JANOWSKY, D.S. and REZVANI, A.H. (1990b) Effectg of bright light on responsiveness to a muscarinic agonist in rats gelectively bred for endogenously increased cholinergic function. Psychiatry Research 33: 139-150.

PAYKEL, E.S. (1989) Treatment of Depression: The relevance of research to clinical practice Brit. J. Paychiat. $155,754-763$.

PECR, J.A. DILSAVER, S.C. and MCGEE, M. (1991) Forced stress produces subsensitivity 
to nicotine. Pharmacol. Biochem. Behav. 38: 501-504.

REHAVI, M. RAMOT, O. YAVETZ, B. and soKoLOVSKY, M. (1980) Amitipiptyline long-term treatment elevates alpha-adrenergic and muscarinic receptor finding in mouse brain. Brain Reg. Rev. 194: 443-453.

RICHELSON, E* and DININETZ-RONERO, s* (1977) Blockade by psychotropic druge on the muscarinic acetylcholine receptor in cultured nerve cells. Blol. paychiatry 13: $771-775$.

SCHOFIELD. G.G. WITTOP, B. WERNIC, J.E. AND ALBUQUERQUE, S.T. (1981) Differentiation of the open and closed states of the lonic channela of nicotinio aoetylcholine receptors by tricyclic antidepressants. PNAS 78 : 5240-5244.

SHAKER, N. ELDEFRAWI, A.T. MILLER, E.R. and ELDETYAWI, K.E. (1981) Interaction of tricyclic antidepressants with the ionic channel of the acetylcholine receptor of Torpedo electric organ. Molecular pharmacol. 20: 515-518.

SHIFRIN, G.S. and KLEIN, W.L. (1980) Regulation of muscarinic acetylcholine receptor concentration in cloned neuroblastoma a system cultures. J. Neurochem. 34: 993-999.

SIMIAN, R.G. and KLEIN, W.L. (1979) Cholinergic activity regulates muscarinic receptors in central nervous system cultures. PNAS 34: 993-999.

SNYDER, S.H., an YAMAMURA, H.I. (1977). Antidepressanta and the muecarinic acetylcholine receptor. Arch. Gen. Bsychiatry 34, 236- 239.

SZABDI, P. GAZNER, P. and BRADSHAW (1972) The peripheral anticholinergic activity of tricyclic antidepreseants: Comparison of amitriptyline and desipramine in human volunteers. Brit. J. Peychiat. 13: 433-439.

TAYLOR, J,E. EL-FAKANAY, E. and RICHELSON, E. (1979) Long-term regulation of muecarinic acetylcholine receptors on cultured nerve cells. Iife sciences 25 : 2181-2187.

TOLLEFSON, G.D. SENOGLES, S.E. FREY, W.H. TUASON, V.B. and NICOL, S.E. (1982) A comparison of peripheral and central human muscarinic chollnergic receptor affinities for peychotropic drugs, Biol. Paychiatry 7: 555-567.

WESTFALL, T.C. (1973) Effect of acetylcholine on the release of [3H]-norepinephrine by nlcotine and potaseium ohloride from rat brain alioes. Bloohem. Pharmacol. 235. 502-504.

YAMADA, S. IOGAI, K. OKUDAIRA, H., and HAYASHI, E. (1983) Reglonal adaptatlon of muscarinic receptors and choline uptake in brain following repeated administration of dilsophrophylfluro-hosphonate and atropine. Brain Res. 268: 315-320.

Inquiries and reprint requesto should be addresaed to:

Steven C. Dilsaver, M.D.

Clinical Research Unit

Harris County Psychiatric Center

2800 South MacGregor Way

Houston, Texas 77021 